\title{
Quantification of the Nitrogen Cycle in a Prairie Stream
}

\author{
Walter K. Dodds, ${ }^{1 *}$ Michelle A. Evans-White, ${ }^{1}$ Nicole M. Gerlanc, ${ }^{1}$ \\ Lawrence Gray, ${ }^{2}$ Dolly A. Gudder, ${ }^{1}$ Melody J. Kemp, ${ }^{1}$ Amanda L. López, ${ }^{1}$ \\ David Stagliano, ${ }^{3}$ Eric A. Strauss, ${ }^{4}$ Jennifer L. Tank, ${ }^{5}$ Matt R. Whiles, ${ }^{3}$ \\ Wilfred M. Wollheim ${ }^{6}$
}

\begin{abstract}
${ }^{1}$ Division of Biology, Ackert Hall, Kansas State University, Manhattan, Kansas, 66506, USA; ${ }^{2}$ Department of Life Science, Utah Valley State College, 800 W. 1200 South, Orem, Utah, 84058, USA; ${ }^{3}$ Department of Entomology, Waters Hall, Kansas State University, Manhattan, Kansas, 66506, USA; ${ }^{4}$ Department of Biological Sciences, University of Notre Dame, Notre Dame, Indiana 46556, USA; ${ }^{5}$ Department of Biological Sciences, University of Notre Dame, Notre Dame, IN 46556, USA; and ${ }^{6}$ The Ecosystems Center, Marine Biological Laboratory, Woods Hole, Massachusetts 02543, USA
\end{abstract}

\begin{abstract}
Nitrogen $(\mathrm{N})$ was added for 35 days in the form of ${ }^{15} \mathrm{NH}_{4} \mathrm{Cl}$ to Kings Creek on Konza Prairie, Kansas. Standing stocks of $\mathrm{N}$ in key compartments (that is, nutrients, detritus, organisms) were quantified, and the amount of labeled $\mathrm{N}$ entering the compartments was analyzed. These data were used to calculate turnover and flux rates of $\mathrm{N}$ cycling through the food web, as well as nutrient transformation rates. Inorganic $\mathrm{N}$ pools turned over much more rapidly in the water column of this stream than in pelagic systems where comparable measurements have been made. As with other systems, the mass of ammonium was low but it was the key compartment mediating nutrient flux through the ecosystem, whereas dissolved organic $\mathrm{N}$, the primary component of $\mathrm{N}$ flux through the system, is not actively cycled. Nitrification was also a significant flux of $\mathrm{N}$ in the stream, with rates in the water column and surface of benthos accounting for ap-
\end{abstract}

\section{INTRODUCTION}

Nitrogen $(\mathrm{N})$ is a key element that often determines the productivity (for example, see Dodds and others 1997) and water quality of streams. Thus, it is im-

Received 2 August 1999; accepted 18 July 2000

*Corresponding author; e-mail: wkdodds@ksu.edu proximately $10 \%$ of the total ammonium uptake. Primary consumers assimilated $67 \%$ of the inorganic $\mathrm{N}$ that entered benthic algae and microbes. Predators acquired $23 \%$ of the $\mathrm{N}$ that consumers obtained. Invertebrate collectors, omnivorous crayfish (Orconectes spp.), and invertebrate shredders dominated the $\mathrm{N}$ flux associated with primary consumers. Mass balance calculations indicated that at least $23 \%$ of the $309 \mathrm{mg}$ of ${ }^{15} \mathrm{~N}$ added during the 35 days of release was retained within the 210-m stream reach during the release. Overall, the rates of turnover of $\mathrm{N}$ in organisms and organic substrata were significantly greater when C:N was low. This ratio may be a surrogate for biological activity with regard to $\mathrm{N}$ flux in streams.

Key words: nitrogen cycle; nitrogen export; C:N ratio; stream; aquatic insects; trophic structure. 
tensively than forested, temperate streams (Matthews 1988). However, almost a third of the runoff from continents across the world originates from grasslands and wooded grasslands (Dodds 1997). At one time, these habitats covered a large part of central temperate North America, but agriculture and urbanization have drastically decreased grassland area since European settlement. We believe that an understanding of the ecosystem function of relatively unaltered grassland streams could aid the efforts to conserve biota such as the Topeka Shiner, Notropis topeka, and the Neosha Madtom, Noturus placidus, (Cross and Collins 1995) and improve water quality.

Early efforts to quantify ecosystem processes in shallow aquatic systems focused on carbon, with some efforts to include N cycling (Odum 1957). With the advance of techniques for measuring microbial fluxes, budgets of $\mathrm{N}$ cycling in shallow freshwater habitats became more detailed (see, for example, Triska and others 1984; Dodds and Castenholz 1988). Still, these studies did not directly verify that small-scale experimental incubations can be extrapolated accurately to ecosystem-level flux rates. For example, without tracers, uptake measurements at ambient $\mathrm{NH}_{4}{ }^{+}$ concentrations are inaccurate and cannot account for remineralization. Most tracer experiments have been done in flasks without making an explicit assessment of bottle effects (see, for example, Dodds and others 1991). The use of isotopic N tracers $\left({ }^{15} \mathrm{~N}\right.$ labeled compounds) in large-scale studies of lakes (see, for example, Dodds and Priscu 1990) and streams (Peterson and others 1997; Hall and others 1998) has now allowed later investigators to minimize bottle effects.

The purpose of this study was to describe the $\mathrm{N}$ cycling and budget for a reach of a pristine tallgrass prairie stream. We added ${ }^{15} \mathrm{NH}_{4} \mathrm{Cl}$ over a 35-day period and quantified its uptake into and export from various biotic and abiotic compartments. This quantification allowed for observations of food web dynamics as well as cycling rates of inorganic and organic $\mathrm{N}$ compounds in the environment. This information allowed us to address several important questions about $\mathrm{N}$ cycling in prairie streams, such as (a) What factors alter retention and transport of $\mathrm{N}$ in grassland streams? (b) Is nitrification a significant flux in $\mathrm{N}$-poor streams with low levels of dissolved $\mathrm{NH}_{4}{ }^{+}$? and (c) How efficient is the stream food web in $\mathrm{N}$ transfer and retention?

\section{Materials AND Methods}

\section{Study Site}

We conducted the study in a 210-m reach of Kings Creek, an upland prairie stream, in watershed N04D of Konza Prairie Biological Station. Detailed descriptions of the geology (Oviatt 1998), hydrology, geochemistry (Gray and others 1998), and ecology (Gray and Dodds 1998) of this stream have been published previously. Prior to European settlement of this area, bison grazing and fire were common on the prairie. The watershed immediately above the experimental reach was burned 1 week prior to the initiation of the experiment and was utilized by bison throughout the study period. Prior research has demonstrated that recent burning and bison grazing increase $\mathrm{N}$ concentrations in these prairie streams by less than $50 \%$ (Dodds and others 1996a).

The experimental stream reach is intermittent, but it flowed continually from December 1997 until the end of the experiment. The physical and chemical characteristics of the stream throughout the experiment are reported in Table 1. The stream had a $1-\mathrm{cm}$ thick layer of stalked diatoms at the beginning of the experiment that sloughed off within the 1st week but had partially reestablished by the end of the experiment.

\section{${ }^{15} \mathrm{~N}$ Release and Analyses}

A solution of $0.23 \mathrm{mM} \mathrm{NH}_{4}{ }^{+}$enriched to $10 \mathrm{~mol} \%$ ${ }^{15} \mathrm{~N}$ was released into the stream at an average rate of $2.2 \mathrm{~mL} \mathrm{~min}^{-1}$. A total of $0.309 \mathrm{~g}{ }^{15} \mathrm{~N}$ was added over the 35-day period commencing on 7 April 1998 and ending on 11 May 1998. Details of sample analysis are described more thoroughly in Mulholland and others (2000). The ${ }^{15} \mathrm{~N}:{ }^{14} \mathrm{~N}$ ratios of all samples were determined at the Ecosystems Center of the Marine Biological Laboratory, Woods Hole, Massachusetts. Enrichment of ${ }^{15} \mathrm{~N}$ was analyzed in dried and finely ground biological samples with a Europa 20/20 mass spectrometer (PDZ Europa, Chesire). Analysis of replicate samples indicated low analytical variation $( \pm 0.5 \%)$. The ${ }^{15} \mathrm{~N}_{-} \mathrm{NH}_{4}{ }^{+}$ was analyzed following an alkaline diffusion procedure (Holmes and others 1998) on a Finnegan Delta $S$ mass spectrometer (Finnegan MAT, Breman). Additional samples were processed for analysis of ${ }^{15} \mathrm{~N}-$ $\mathrm{NO}_{3}{ }^{-}$by boiling under basic conditions to concentrate $\mathrm{NO}_{3}{ }^{-}$and drive off $\mathrm{NH}_{3}$. Then ${ }^{15} \mathrm{~N}_{-} \mathrm{NO}_{3}{ }^{-}+$ $\mathrm{NO}_{2}{ }^{-}$was converted to ammonia with DeVarda's Alloy, concentrated by diffusion, and analyzed as above (Sigman and others 1997).

Nutrient samples were analyzed for total $\mathrm{N}$ fol- 
Table 1. Physical and Chemical Characteristics of the Study Reach over the Study Period

\begin{tabular}{|c|c|c|c|}
\hline Attribute (date) & Value (units) & Attribute & Value (units) \\
\hline Gradient & $2 \%$ & $\mathrm{NH}_{4}^{+}$ & $0.13 \pm 0.001 \mu \mathrm{M}$ \\
\hline Length & $210 \mathrm{~m}$ & $\mathrm{NO}_{3}^{-}+\mathrm{NO}_{2}^{-}$ & $0.19 \pm 0.02 \mu \mathrm{M}$ \\
\hline Average width (19 May) & $2.4 \mathrm{~m}$ & Total N & $17 \pm 2.2 \mu \mathrm{M}$ \\
\hline Total surface area (19 May) & $504 \mathrm{~m}^{2}$ & Soluble reactive $\mathrm{P}$ & $0.07 \pm 0.038 \mu \mathrm{M}$ \\
\hline$\%$ riffle + run & 81 & Total P & $0.35 \pm 0.10 \mu \mathrm{M}$ \\
\hline$\%$ pool & 19 & $\mathrm{pH}$ & 8.2 \\
\hline \% fine (sand, silt, clay) & 29 & $\begin{array}{l}\text { Gross primary production (diel } \mathrm{O}_{2} \\
\text { change method) }\end{array}$ & $1.8 \mathrm{~g} \mathrm{O}_{2} \mathrm{~m}^{-2} \mathrm{~d}^{-1}$ \\
\hline$\%$ gravel/cobble & 53 & Respiration (diel $\mathrm{O}_{2}$ change method) & $2.4 \mathrm{~g} \mathrm{O}_{2} \mathrm{~m}^{-2} \mathrm{~d}^{-1}$ \\
\hline$\%$ boulder/bedrock & 18 & $\mathrm{P}: \mathrm{R}$ ratio & 0.75 \\
\hline Mean discharge & $15.8 \mathrm{~L} \mathrm{~s}^{-1}$ & Limiting nutrient to periphyton & $\mathrm{N}+\mathrm{P}$ \\
\hline Max discharge (7 April) & $41.8 \mathrm{~L} \mathrm{~s}^{-1}$ & PAR & $\begin{array}{l}34.5 \pm 4.3 \mathrm{~mol} \\
\text { quanta } \mathrm{m}^{-2} \mathrm{~d}^{-1}\end{array}$ \\
\hline Min discharge (2 June) & $2.4 \mathrm{~L} \mathrm{~s}^{-1}$ & $\alpha$ & $0.0001 \mathrm{~s}^{-1}$ \\
\hline Water temperature & $15.5 \pm 0.63^{\circ} \mathrm{C}$ & $\mathrm{A}_{\mathrm{s}} / \mathrm{A}$ & 0.165 \\
\hline
\end{tabular}

lowing persulfate digestion (Ameel and others 1993) and for $\mathrm{NO}_{3}{ }^{-}$using a cadmium reduction method on an autoanalyzer (Technicon Autoanalyzer II 1973). Samples were analyzed spectrophotometrically for $\mathrm{NH}_{4}{ }^{+}$by the phenol hypochlorite method (American Public Health Association 1995). Glassware was kept scrupulously clean, and a 5-cm cell was used for $\mathrm{NH}_{4}{ }^{+}$analyses. The limits of detection, as determined by the upper $95 \%$ confidence level of the y intercept of the plot of absorbance vs concentration, were typically $1 \mu \mathrm{g} \mathrm{L}^{-1}$ for $\mathrm{NO}_{3}{ }^{-}$and $0.2 \mu \mathrm{g} \mathrm{L}^{-1}$ for $\mathrm{NH}_{4}{ }^{+}$.

\section{Benthic Mass Estimation}

Mass of all compartments was determined in riffles (runs were included in the riffle category for this study) and pools. The study reach was mapped and all biomass and production values were habitatweighted by surface area of riffles and pools. Dry mass and ash-free dry mass (AFDM) were determined by standard methods. The $\mathrm{N}$ content was determined on a Carlo Erba Elemental Analyzer (CE Instruments, Milan) at the Institute of Ecology, University of Georgia.

\section{Fauna}

Quantitative macroinvertebrate samples were collected with a metal core sampler $\left(313-\mathrm{cm}^{2}\right.$ sampling area) from the two major habitats (riffles and pools) in a stratified, random fashion on March 22 (three riffles), April 4 (five pools), April 22 (three riffles), and May 5 (five pools). Pools were sampled more intensively because invertebrate numbers were more variable there than in riffles. For each sample, sediments enclosed by the corer were disturbed by hand to a depth of at least $10 \mathrm{~cm}$, and invertebrates were collected on a $250-\mu \mathrm{m}$ sieve from the suspension of particles created by the disturbance. Samples were either preserved in an $8 \%$ formalin solution or frozen for later analysis.

In the laboratory, specimens were identified to the lowest possible taxon, total body length and dry mass (DM) were measured, and subsamples were frozen for analysis of $\mathrm{N}$ content. Length-weight regressions developed from our data or equations presented by Benke and others (1999) were used to estimate individual AFDM from body length.

Fish and crayfish colonized the study reach 2 weeks after initiation of the ${ }^{15} \mathrm{~N}$ tracer addition. Therefore, biomass was sampled 2 days after tracer addition stopped (14 May 1998). One riffle site at $270 \mathrm{~m}$ and one pool site $70 \mathrm{~m}$ downstream of the ${ }^{15} \mathrm{~N}$ addition site were sampled successively with a backpack shocker until few or no organisms were obtained (Van Den Avyle 1993). Standard length (nearest $1 \mathrm{~mm}$ ) of fish and carapace length (nearest $0.01 \mathrm{~mm}$ ) of crayfish were determined for all individuals sampled. We established length-weight relationships to calculate total biomass. Population estimates were obtained using the Leslie depletion method (Van Den Avyle 1993).

Production of selected taxa was estimated for the period of the ${ }^{15} \mathrm{~N}$ addition with the instantaneous growth method (Benke 1984). The trophic basis of 
production for crayfish and estimates of consumption by insect taxa were derived using methods described by Benke and Wallace (1980). Crayfish instantaneous growth rates were calculated using data on carapace lengths at various ages from Momot (1984) and H. Klaassen (personal communication). Food preference and assimilation efficiency (AE) estimates for crayfish were obtained from Whitledge (1996). Estimates of net production efficiencies (NPE) for aquatic invertebrates and AE values for various food types were obtained from Lawton (1970), Benke and Wallace (1980), and Perry and others (1987).

\section{Primary Producer Biomass}

Epilithon was sampled quantitatively in pools and riffles by scrubbing and washing all material within a $174-\mathrm{cm}^{2}$ area from replicate rocks. The collected material was filtered onto Whatman GF/F filters, dried, weighed, and analyzed for AFDM and N content. Four separate bryophyte samples were collected in riffles (none occurred in pools). For each sample, all bryophytes within $1 \mathrm{~m}^{2}$ were collected and subsamples were taken to determine AFDM $\mathrm{m}^{-2}$. The bases of the moss were heavily calcified and not biologically active (labeled weakly with ${ }^{15} \mathrm{~N}$ ) (Mulholland and others 2000). Therefore, only the biomass of actively growing (light green) tips is reported. Biomass of filamentous green algae in both riffles and pools was determined with the same method used for bryophytes.

\section{Coarse, Fine, and Suspended Organic Nitrogen}

Leaves, small wood, and fine benthic organic $\mathrm{N}$ (FBON) were collected from inside a $313-\mathrm{cm}^{2}$ corer; four samples were collected from riffles and four from pools. All small wood and leaves were removed carefully from the isolated stream bottom, then FBON was collected using gentle suction to remove all affixed material from the isolated surface. Large wood was rare and not sampled. Suspended particulate organic $\mathrm{N}$ (SPON) was sampled by pumping a known volume of stream water through a preweighed Whatman GF/F glass fiber filter, and $\mathrm{g} \mathrm{AFDM} \mathrm{L}{ }^{-1}$ and $\mathrm{g} \mathrm{L}^{-1}$ were determined as described above.

\section{Collection for ${ }^{15} \mathrm{~N}$ Analyses}

Eight stations were selected for qualitative sampling of food web compartments for ${ }^{15} \mathrm{~N}$ content. Stations were located $10 \mathrm{~m}$ above the point of ${ }^{15} \mathrm{~N}$ addition and 30, 50, 70, 100, 120, 170, and $210 \mathrm{~m}$ below it. All biotic compartments were sampled weekly, from 1 week before the initiation of the ${ }^{15} \mathrm{~N}$ release until 2 weeks after cessation of the release. Samples were also taken 1 month after termination of the ${ }^{15} \mathrm{~N}$ release (the sampling dates were $6,14,21$, and 28 April, and 5, 12, 19, and 26 May). Some compartments such as epilithon, filamentous green algae, $\mathrm{NH}_{4}{ }^{+}$, and $\mathrm{NO}_{3}{ }^{-}$that turn over rapidly were sampled more frequently when the release was initiated and again when it was terminated. All solid samples were returned to the laboratory on ice, processed within $24 \mathrm{~h}$ of collection, dried at $60^{\circ} \mathrm{C}$, and ground before analysis (see detailed description in Mulholland and others 2000).

The SPON was sampled by pumping stream water through a Whatman GF/F glass fiber filter until it clogged. The FBON was sampled by gentle suction of a sample from the stream bottom. Small wood, leaves, and filamentous green algae were handpicked from the stream. Epilithon was scraped from rocks and washed into plastic sample jars. Bryophytes were handpicked from rocks, and the actively growing tips were cut from bases for analysis.

Macroinvertebrate samples were collected with kick nets (0.5-mm mesh). Additional fish and crayfish samples were collected by seine. Samples were handpicked in the field and segregated to avoid losses to predation. In the laboratory, specimens were sorted by functional feeding group into clean plastic jars and placed in clean water at $4^{\circ} \mathrm{C}$ for $12 \mathrm{~h}$ to allow their guts to void. Samples then were dried and ground for later ${ }^{15} \mathrm{~N}$ analyses.

\section{Nitrification Rates}

Nitrification rates were determined in the laboratory for microbes associated with substrate samples of FBOM, diatoms, green algae, woody debris, and leaves using the nitrification inhibitor, nitrapyrin (Hall 1984). Each nitrification replicate in the experiment consisted of samples in two polycarbonate tubes $(3.8 \mathrm{~cm}$ inner diameter $\times 35 \mathrm{~cm}$ length) with one end of each tube sealed with a rubber stopper. Approximately $40 \mathrm{~cm}^{3}$ of substrate sample and 150 $\mathrm{mL}$ stream water were added to both tubes for each of these replicates. One tube received $10 \mathrm{mg} \mathrm{L}^{-1}$ (final concentration) nitrapyrin (dissolved in $10 \mu \mathrm{L}$ DMSO). The other tube received an equal volume of DMSO as a control. The tubes were covered individually with aluminum foil and incubated in the dark at ambient stream temperature for 3 days on an orbital shaker (175 rpm). Then $\mathrm{NH}_{4}{ }^{+}$concentrations were determined on filtered $1 \mathrm{~N} \mathrm{KCl}$ extracts from each tube using the phenol hypochlorite method (APHA 1995). Nitrification rates were calculated from the difference in $\mathrm{NH}_{4}{ }^{+}$concentration between the contents of the tubes that con- 
tained nitrapyrin dissolved in DMSO and those that contained only DMSO. Samples were weighed following analysis and biomass estimates were used to scale rates up to whole-stream estimates. Wholestream nitrification rates also were determined by analyzing the loss of ${ }^{15} \mathrm{NH}_{4}{ }^{+}$and the gain of ${ }^{15} \mathrm{NO}_{3}{ }^{-}$ while accounting for stream dilution and biotic uptake (see calculations below).

\section{N Flux Calculations}

Several methods were used to calculate $\mathrm{N}$ fluxes, depending upon the data available. ${ }^{15} \mathrm{~N}$ label in each sample is represented as a $\delta^{15} \mathrm{~N}$ value calculated as

$$
\delta^{15} N=\left[\left(\frac{R_{\text {compartment }}}{R_{\text {standard }}}\right)-1\right] \times 1000
$$

where $R_{\text {compartment }}$ is the ${ }^{15} \mathrm{~N} /{ }^{14} \mathrm{~N}$ analyzed in the sample from a compartment, and $R_{\text {standard }}=$ 0.003663 .

The $\mathrm{N}$ turnover rate for each compartment was calculated from the decrease in $\delta^{15} \mathrm{~N}$ values after the addition stopped. The basic equation for this calculation is

$$
\text { Turnover } N_{\text {compartment }}=\frac{d\left(\ln \delta^{15} N_{\text {compartment }}\right)}{d t}
$$

where turnover of $\mathrm{N}$ in the specified compartment (per unit time) is the slope of the natural log of the label in the compartment over time. Turnover and uptake rates of the dissolved $\mathrm{NH}_{4}{ }^{+}$compartment were too rapid to calculate by Eq. (2) given our sampling frequency, so they were calculated by uptake of label over distance:

$$
\text { Uptake length } N_{\text {compartment }}=\frac{\frac{1}{d\left(\ln \delta_{\text {compartment }}\right)}}{d x}
$$

The uptake length (the average distance traveled in the water column, or spiral length, $\mathrm{S}_{\mathrm{w}}$ ) (Webster and Ehrman 1996) is the inverse of the slope of the change in label in the pool as a function of distance $(\mathrm{x})$. Change in $\delta^{15} \mathrm{~N}$ values over distance as a consequence of groundwater dilution was corrected using data from releases of the conservative tracer bromide (Webster and Ehrman 1996). Uptake length and dilution were measured three times during our study (8 April, 27 April, and 12 May). Ammonium uptake length was converted to an uptake rate given the total $\mathrm{NH}_{4}{ }^{+}$concentration, discharge, and average width of the channel as follows:

$$
\text { Uptake rate }=\frac{\left[\mathrm{NH}_{4}^{+}\right] \times \text {discharge }}{\text { width } \times \text { uptake length } \mathrm{NH}_{4}{ }^{+}}
$$

This equation is derived from the equations described by the Stream Solute Workshop (1990).

Turnover rate is related to uptake flux and biomass, as follows:

$$
\text { Turnover rate }=\frac{\text { uptake rate }}{\text { mass } N}
$$

When ${ }^{15} \mathrm{NH}_{4}{ }^{+}$values returned close to background levels after addition stopped, turnover calculated by Eq. (2) was used to estimate uptake rates. However, turnover rate was underestimated by taking the slope of the log of label versus time when ${ }^{15} \mathrm{~N}$ tracer continued to enter the $\mathrm{N}$ in a compartment. For example, grazers continued to eat ${ }^{15} \mathrm{~N}$-enriched algae after ${ }^{15} \mathrm{~N}$ addition stopped. In these cases, a box model was used to estimate uptake rates, and Eq. (5) was used to calculate turnover rates.

The box model approach to modeling $\mathrm{N}$ fluxes through ecosystem compartments is described in detail by Hall and others (1998) and Wollheim and others (1999) and is based, in part, on concepts developed by Crossley and Reichle (1969). A description of the basic assumptions of the model is given here to assist the reader in interpreting our data and calculations. In this study, we modeled individual compartments (boxes) in the same way as the general ecosystem model. We varied uptake rate until the observed label matched the predicted label in the compartment of interest. The model assumed steady state (for example, constant biomass and uptake rates).

In our version of this model,

$$
\text { Uptake rate }=\text { remineralization rate }+ \text { growth }
$$

The rate at which ${ }^{15} \mathrm{~N}$ and ${ }^{14} \mathrm{~N}$ are acquired is calculated as

$$
\begin{array}{r}
\text { Uptake }{ }^{15} N_{\text {compartment }}=\text { uptake rate } \times R_{\text {source }} \\
\text { Uptake }{ }^{14} N_{\text {compartment }}=\text { uptake rate } \times\left(1-R_{\text {source }}\right)
\end{array}
$$

where $R_{\text {source }}$ is the average label in the source over time. Errors associated with source averaging are documented by Laws (1984).

Remineralization rates were calculated in a similar fashion, except that they were based upon the average ${ }^{15} \mathrm{~N} /{ }^{14} \mathrm{~N}$ ratio of the compartment of interest (they assume complete mixing of the label in the compartment before remineralization).

In our model, we used the known values of ${ }^{15} \mathrm{~N}$ tracer in the source and uptake compartments over 
time at a single station. The uptake rate then was varied until the observed label in the compartment most closely matched (subjectively determined) the calculated label. Some sensitivity analyses of the model are presented in the results. The modeling was repeated for each station where we had enough data.

A modeling approach using data on distribution of labeled nitrate over distance was used to calculate nitrification. Modeling was necessary because there is no analytical solution for the balance between uptake and remineralization (Dodds 1993). Details of a similar model are described in Mulholland and others (2000). In this case, data on ${ }^{15} \mathrm{NO}_{3}{ }^{-}$ and ${ }^{15} \mathrm{NH}_{4}{ }^{+}$over distance were used. Our model varied from theirs in accounting for ${ }^{14} \mathrm{~N}_{-} \mathrm{NO}_{3}{ }^{-}$as well as ${ }^{15} \mathrm{~N}$ and in calculating the instream $\mathrm{NO}_{3}{ }^{-}$ concentration based on uptake and remineralization. A 100-m segment of stream was modeled over 1 -m sections. The change in $\mathrm{NO}_{3}{ }^{-}$concentration over distance was assumed to be zero (because we could detect no trends in measured nitrate concentration over distance). Thus, we assumed that

$$
\text { nitrification rate }=\text { uptake-groundwater influx }
$$

Dilution values from bromide additions were used to estimate groundwater influx for each $1-\mathrm{m}$ section in this model. The ${ }^{15} \mathrm{~N}$ tracer in the $\mathrm{NO}_{3}{ }^{-}$ and $\mathrm{NH}_{4}{ }^{+}$compartments and absolute concentration of $\mathrm{NO}_{3}{ }^{-}$over the stream reach were used as known values. Nitrification and uptake rates were varied until calculated ${ }^{15} \mathrm{~N}$ label in, and concentration of the $\mathrm{NO}_{3}{ }^{-}$matched observed values. The model of Mulholland and others (2000) was also used to estimate nitrification rates and the results were similar.

\section{RESULTS}

Nitrogen standing stocks in this stream were dominated by FBON (Table 2). Invertebrate predators (45 $\mathrm{mg} \mathrm{N} \mathrm{m}^{-2}$ ) constituted a high biomass relative to that of other animals in the stream $(59 \mathrm{mg} \mathrm{N}$ $\mathrm{m}^{-2}$ ). Bryophytes and epilithon also contained significant portions of the standing stock of N. Dissolved inorganic $\mathrm{N}$ pools were small relative to dissolved organic N. As would be expected, animals had lower $\mathrm{C}: \mathrm{N}$ ratios than primary producers and detrital pools (Table 2).

Ceratopogonids (primarily Bezzia and Palpomyia) dominated the invertebrate predator compartment, oligochaetes were the most common collectors, the snail Physa dominated the scrapers, and Tipula was
Table 2. Nitrogen Biomass and C:N Ratio of Ecosystem Compartments, Ordered by N Mass

\begin{tabular}{lcc}
\hline Compartment & $\begin{array}{l}\text { Biomass } \\
\left(\mathrm{mg} \mathrm{N} \mathrm{m}^{-2}\right)\end{array}$ & C:N (weight) \\
\hline $\mathrm{NH}_{4}{ }^{+}$ & 0.08 & \\
$\mathrm{SPON}^{-}$ & 0.33 & 9.0 \\
$\mathrm{NO}_{3}{ }^{-}$ & 0.35 & \\
Etheostoma spectabile & 1.0 & 3.9 \\
Campostoma & 1.4 & \\
Crayfish & 10.3 & 4.6 \\
Scrapers & 10 & \\
Collectors & 16 & 4.1 \\
Filamentous green algae & 14 & 24.0 \\
Leaves & 16 & 29.4 \\
Shredders & 22 & \\
Wood & 20 & 41.7 \\
Dissolved organic N & 21 & \\
Bryophytes & 31 & 24.3 \\
Invertebrate predators & 45 & \\
Epilithon & 359 & 25.5 \\
FBon & 1139 & 17.0 \\
&
\end{tabular}

the most abundant shredder (Table 3). We separated biomass of crayfish (Orconectes spp.) and stonerollers (Campostoma anomalum) from the other compartments because of their potential for omnivory and because prior research indicated that these species may be important determinants of ecosystem structure (see, for example, Matthews and others 1987; Whitledge and Rabeni 1997). We used growth data (Table 4) to compare production among various invertebrate groups and to account for $\mathrm{N}$ assimilation for growth (production) during $\mathrm{N}$ flux calculations [Eq. (6)].

Crayfish biomass was as high as most other invertebrate groups. We used published values to estimate food sources and trophic basis of production for these abundant omnivores (Table 5). These data were used to parameterize our final model. Fish biomass was low relative to many other consumers in the stream.

N Turnover and Flux through Inorganic, Organic, and Detrital Pools

Ammonium turnover in the water column was calculated using the decrease in ${ }^{15} \mathrm{~N}$ label with distance downstream from the point of tracer addition [Eq. (3)]. A wide range of flux rates (from 1 to $55 \mathrm{mg} \mathrm{N}$ $\mathrm{m}^{-2} \mathrm{~d}^{-1}$ ) was obtained on the 3 separate days when this was estimated. This range is also reflected in the uptake lengths (that is, the average length an $\mathrm{NH}_{4}{ }^{+}$ molecule remains in the water column). The longest uptake length corresponded with the highest dis- 
Table 3. Biomass, \% N, and Standing Stock N for Dominant Taxa in each Functional Group of Animals

\begin{tabular}{|c|c|c|c|}
\hline Group and Taxa & $\begin{array}{l}\text { Biomass } \\
\left(\mathrm{mg} / \mathrm{m}^{2}\right)\end{array}$ & $\% \mathrm{~N}$ & $\begin{array}{l}\mathrm{N} \\
\left(\mathrm{mg} / \mathrm{m}^{2}\right)\end{array}$ \\
\hline \multicolumn{4}{|l|}{ Predators } \\
\hline Perlesta placida & 85 & 9.02 & 7.67 \\
\hline Ceratopogonidae & 229 & 9.02 & 20.63 \\
\hline Pseudolimnophila sp. & 140 & 9.02 & 12.66 \\
\hline Other $^{a}$ & 20 & 9.02 & 1.85 \\
\hline Total Predators & 496 & & 44.66 \\
\hline \multicolumn{4}{|l|}{ Collectors } \\
\hline Oligochaeta & 67 & 8.25 & 5.55 \\
\hline Baetidae & 17 & 8.25 & 1.43 \\
\hline Chironomidae & 42 & 8.25 & 3.47 \\
\hline Other $^{b}$ & 28 & 8.25 & 2.34 \\
\hline Total Collectors & 196 & & 16.30 \\
\hline \multicolumn{4}{|l|}{ Scrapers } \\
\hline Physa sp. & 70 & 9.57 & 6.72 \\
\hline Stenonema femoratum & 27 & 9.57 & 2.61 \\
\hline Total Scrapers & 110 & & 10.42 \\
\hline \multicolumn{4}{|l|}{ Shredders } \\
\hline Zealeuctra claasseni & 1.5 & 7.17 & 0.10 \\
\hline Tipula spp. & 251 & 7.17 & 17.98 \\
\hline Total Shredders & 306 & & 22.41 \\
\hline \multicolumn{4}{|l|}{ Omnivores } \\
\hline $\begin{array}{l}\text { Orconectes spp. } \\
\text { Campostoma }\end{array}$ & 128 & 8.02 & 10.29 \\
\hline anomalum & 14 & 10.02 & 1.44 \\
\hline \multicolumn{4}{|l|}{ Vertebrate Predator } \\
\hline Etheostoma spectabile & 15 & 9.02 & 1.26 \\
\hline
\end{tabular}

charge (Table 6). Temperature apparently had a weaker effect on uptake length. Turnover of the $\mathrm{NH}_{4}{ }^{+}$ pool was the fastest of any measured pool (Table 7).

Nitrification and $\mathrm{NO}_{3}{ }^{-}$uptake were compared through whole-stream measurements using ${ }^{15} \mathrm{NO}_{3}$ data and laboratory incubations. The laboratory nitrification incubation results were scaled to the entire reach and yielded an estimate of $77 \mathrm{mg} \mathrm{m}^{-2}$ $\mathrm{d}^{-1}$. This number cannot represent the water column nitrification rates because the estimates of water column $\mathrm{NH}_{4}{ }^{+}$supply (remineralization from turnover calculations) are about one-sixth of this level. The model estimate of nitrification in the water column and shallow benthos gave a rate of $0.2 \mathrm{mg} \mathrm{m}^{-2} \mathrm{~d}^{-1}$. This estimate should be viewed with caution because enrichment of the nitrate pool was low and variable. A third method of calculating nitrification rate is to use Eq. (9) and estimate $\mathrm{NO}_{3}{ }^{-}$ uptake rates. The amount of groundwater dilution was less than $1 \%$ per $\mathrm{m}^{2}$, so uptake should approximate nitrification. We calculated uptake rate of $\mathrm{NO}_{3}{ }^{-}$from previous pulsed $\mathrm{NO}_{3}{ }^{-}$additions. We used $\mathrm{NO}_{3}{ }^{-}$uptake of a variety of concentrations to extrapolate to rates at ambient concentrations (López and Dodds unpublished). The $\mathrm{NO}_{3}{ }^{-}$uptake rate calculated with this method was $2.64 \mathrm{mg} \mathrm{m}^{-2}$ $\mathrm{d}^{-1}$.

Dissolved organic $\mathrm{N}$ (DON) turned over very slowly relative to $\mathrm{NO}_{3}{ }^{-}$and $\mathrm{NH}_{4}{ }^{+}$(Table 7). Calculated DON production and turnover rates represent maxima. The ${ }^{15} \mathrm{~N}$ label was not significantly higher than background; therefore, DON flux was estimated as the maximum that could occur without increasing ${ }^{15} \mathrm{~N}$ enrichment significantly (given the variance in ${ }^{15} \mathrm{~N}$-DON values). Thus, our estimate probably represents an overestimate of the actual turnover of the DON pool.

Suspended particulate organic N turned over rapidly relative to dissolved organic $\mathrm{N}$ and most other pools of $\mathrm{N}$ (Table 7). This turnover flux was best estimated by the decrease in label over time after the ${ }^{15} \mathrm{~N}$ tracer addition was stopped. Given the low concentrations of SPON in the water column at any one time compared to other organic $\mathrm{N}$ pools, the flux rate expressed per unit area was relatively low (similar to DON).

Wood and leaves were both labeled weakly, and their uptake flux and turnover rates were calculated using the box model (Table 7). Both turnover rates were extremely slow, leading to low total $\mathrm{N}$ flux rates, even though these compartments had a substantial mass of $\mathrm{N}$ per unit area. The FBON had low to moderate turnover rates (depending upon whether they were calculated with the model or the turnover method). The absolute flux rates associated with the FBON were high when expressed per unit area because of the large standing stock of $\mathrm{N}$ in this compartment.

\section{N Turnover and Flux through Primary Producers}

Epilithon had greater total $\mathrm{N}$ flux rates compared to bryophytes or filamentous green algae (Table 7), primarily because of its greater biomass. Flux rates for the three primary producer compartments all were calculated using the box model. As a comparison, turnover was calculated for epilithon and filamentous green algae using the $\delta^{15} \mathrm{~N}$ loss rate of label after the ${ }^{15} \mathrm{~N}$ addition was terminated. In both cases, $\mathrm{N}$ turnover was greater when calculated by the latter method. Low $\mathrm{N}$ turnover rates in bryophytes led to low absolute $\mathrm{N}$ flux rates.

The $\delta^{15} \mathrm{~N}$ values for epilithon from a single 
Table 4. Habitat-Weighted Biomass, Daily Growth, Production, and Consumption of Focal Invertebrate Taxa during the Period of the ${ }^{15} \mathrm{~N}$ Release

\begin{tabular}{|c|c|c|c|c|c|c|}
\hline Taxa & $\begin{array}{l}\text { Mean } \\
\text { Biomass } \\
\left(\mathrm{mg} \mathrm{m}^{-2}\right)\end{array}$ & $\begin{array}{l}\text { Growth }^{a} \\
\left(d^{-1}\right)\end{array}$ & $\begin{array}{l}\text { Daily } \\
\text { Production } \\
\left(\mathrm{mg} \mathrm{m}^{-2} \mathrm{~d}^{-1}\right)\end{array}$ & Days & $\begin{array}{l}\text { Production } \\
\text { during } \\
\text { Interval } \\
\left(\mathrm{mg} \mathrm{m}^{-2}\right)\end{array}$ & $\begin{array}{l}\text { Consumption }^{\mathrm{b}} \\
\text { during } \\
\text { Interval } \\
\left(\mathrm{mg} \mathrm{m}^{-2}\right)\end{array}$ \\
\hline Baetidae & 17 & 0.045 & 0.77 & 35 & 0.44 & 1600 \\
\hline Perlesta placida & 85 & 0.024 & 2.03 & 35 & 71 & 167 \\
\hline Physa sp. & 70 & 0.061 & 4.25 & 35 & 149 & 992 \\
\hline Zealeuctra claasseni & 1.5 & 0.022 & 0.03 & 35 & 1.1 & 21 \\
\hline
\end{tabular}

Table 5. Procedure for Calculating Production (P) Attributed to Food Types and Amount of Food Types Consumed (C) for Orconectes spp. during the Study Period

\begin{tabular}{|c|c|c|c|c|c|c|c|c|}
\hline Food Type & $\begin{array}{l}\text { \% Food } \\
\text { Type in } \\
\text { Gut }\end{array}$ & $\mathrm{AE}$ & NPE & $\begin{array}{l}\text { Relative } \\
\text { Amount } \\
\text { Attributed } \\
\text { to } \mathrm{P}^{a}\end{array}$ & $\begin{array}{l}\% \mathrm{P} \\
\text { Attributed } \\
\text { to Food } \\
\text { Type }\end{array}$ & $\begin{array}{l}\text { P Attributed } \\
\text { to Food } \\
\text { Type }^{b}(\mathrm{mg} \\
\left.\mathrm{m}^{-2} \mathrm{~d}^{-1}\right)\end{array}$ & $\begin{array}{l}\mathrm{P}^{c} \\
\left(\mathrm{mg} \mathrm{m}^{-2}\right)\end{array}$ & $\begin{array}{l}\mathrm{C}^{d} \\
\left(\mathrm{mg} \mathrm{m}^{-2}\right)\end{array}$ \\
\hline Algae & 7 & 0.39 & 0.5 & 1.37 & 15 & 0.19 & 6.7 & 34 \\
\hline Invertebrates & 10 & 0.92 & 0.5 & 4.60 & 50 & 0.64 & 22.4 & 49 \\
\hline CPOM & 52 & 0.14 & 0.38 & 2.77 & 30 & 0.38 & 13.3 & 250 \\
\hline FPOM & 31 & 0.05 & 0.33 & 0.51 & 6 & 0.07 & 2.5 & 152 \\
\hline Total & & & & & & & 44.9 & 485 \\
\hline \multicolumn{9}{|c|}{$\begin{array}{l}\text { Daily production was estimated at } 1.28 \mathrm{mg} \mathrm{m}^{-2} d^{-1} \text { using the instantaneous growth method. } \\
\text { Gut contents and assimilation efficiencies (AE) are from Whitledge (1996). } \\
\text { Net production efficiencies (NPE) for food types are based on Lawton (1970), Benke and Wallace (1980), and Perry and others (1987). } \\
{ }^{a} \text { Calculated as the percentage in gut } \times A E \times N P E \\
{ }^{b} \text { Calculated as daily production } \times \% \text { attributed to food type } \\
{ }^{c} \text { Calculated as } P \text { attributed to food type } \times 35 \text { days } \\
{ }^{d} \text { Calculated as } P /(A E \times N P E)\end{array}$} \\
\hline
\end{tabular}

Table 6. Uptake Length for Ammonium Related to Temperature and Discharge

\begin{tabular}{llll}
\hline Date & $\begin{array}{l}\text { Uptake } \\
\text { Length } \\
(\mathrm{m})\end{array}$ & $\begin{array}{l}\text { Temperature } \\
\left({ }^{\circ} \mathrm{C}\right)\end{array}$ & $\begin{array}{l}\text { Discharge } \\
\left(\mathrm{L} \mathrm{s} \mathrm{s}^{-1}\right)\end{array}$ \\
\hline 8 April & 228 & 12 & 41 \\
27 April & 56 & 11 & 9 \\
12 May & 38 & 15 & 14 \\
\hline
\end{tabular}

station (50 m downstream from the drip) illustrate the difficulty of fitting the model output to the field tracer data (Figure 1B). The very sharp drop in ${ }^{15} \mathrm{~N}$ label after the tracer addition was stopped could not be matched with the steady state model. However, sensitivity analysis of the model showed that a poorer fit resulted when the uptake value judged to give the best fit was doubled or halved.

\section{N Turnover and Flux through Animals}

Baetid mayflies (our representative collector) and Zealeuctra claasseni (the representative shredder) both were labeled more than their potential food resources (Figure 2), suggesting that these organisms were selecting or assimilating the more active portion of their food resource. Our sampling protocols included only bulk food resources. We were not able to model $\mathrm{N}$ uptake of either consumer directly and instead used $\delta^{15} \mathrm{~N}$ decreases after the tracer addition ended to estimate their $\mathrm{N}$ turnover rates. Turnover values for Campostoma, scrapers, crayfish, invertebrate predators, and vertebrate predators could be calculated with both the model and ${ }^{15} \mathrm{~N}$ techniques. For invertebrate predators, the box model fit the observed $\delta^{15} \mathrm{~N}$ data reasonably well, and sensitivity analysis showed how changing the uptake rate changed 
Table 7. Turnover and Flux Calculations for Major Ecosystem Compartments Arranged by Trophic Level

\begin{tabular}{|c|c|c|c|c|c|}
\hline Compartment & $\begin{array}{l}\text { Turnover } \\
\left(d^{-1}\right)\end{array}$ & $\begin{array}{l}\text { Turnover, } \\
\text { Modeled } \\
\left(\mathrm{d}^{-1}\right)\end{array}$ & $\begin{array}{l}\text { Flux }\left(\mathrm{mg} \mathrm{m}^{-2}\right. \\
\left.\mathrm{d}^{-1}\right)\end{array}$ & Range & $\begin{array}{l}\text { Calculation Method } \\
\text { (Comments) }\end{array}$ \\
\hline $\mathrm{NH}_{4}^{+}$ & 119.00 & nc & 12.200 & $1-55$ & Turnover method (three dates) \\
\hline Dissolved organic N & nc & 0.0024 & 0.050 & nc & $\begin{array}{l}\text { Maximum rate (limit of } \\
\text { detection) }\end{array}$ \\
\hline $\mathrm{NO}_{3}{ }^{-}$ & nc & 4.0249 & 1.420 & $0.2-2.64$ & Nitrification/uptake model \\
\hline SPON & 0.18 & nc & 0.060 & $0.01-0.35$ & Turnover method (two stations) \\
\hline Wood & nc & 0.0004 & 0.008 & $0-0.03$ & Box model (three stations) \\
\hline FBON & 0.05 & 0.0040 & 4.500 & $2-7$ & Box model (one station) \\
\hline Leaves & nc & 0.0002 & 0.004 & $0.0035-0.004$ & Box model (one station) \\
\hline Bryophytes & nc & 0.0013 & 0.040 & $0.03-0.05$ & Box model (two stations) \\
\hline Epilithon & 0.71 & 0.0049 & 2.170 & $1.24-3.72$ & Box model (two stations) \\
\hline $\begin{array}{l}\text { Filamentous green } \\
\text { algae }\end{array}$ & 0.17 & 0.0214 & 0.300 & $0.2-0.4$ & Box model (two stations) \\
\hline Collectors & 0.18 & nc & 2.279 & nc & $\begin{array}{l}\text { Turnover method using Baetidae } \\
\text { data (one station) }\end{array}$ \\
\hline Scrapers & 0.09 & 0.0161 & 0.150 & $0.1-0.2$ & $\begin{array}{l}\text { Box model (using snail and } \\
\text { epilithon data), (two stations) }\end{array}$ \\
\hline Shredders & 0.09 & nc & 1.620 & nc & $\begin{array}{l}\text { Turnover method using } \\
\text { Ironoquia punctatissima }\end{array}$ \\
\hline Campostoma & 0.08 & 0.0347 & 0.050 & nc & Box model (one station) \\
\hline Crayfish & 0.07 & 0.2106 & 1.750 & $0.5-3$ & $\begin{array}{l}\text { Box model (two species, one } \\
\text { station) }\end{array}$ \\
\hline $\begin{array}{l}\text { Invertebrate } \\
\text { predator }\end{array}$ & 0.03 & 0.0257 & 1.100 & $0.9-1.3$ & $\begin{array}{l}\text { Box model (using Perlesta data } \\
\text { for predator, Baetidae for } \\
\text { prey), (two stations) }\end{array}$ \\
\hline $\begin{array}{c}\text { Etheostomsa } \\
\text { spectabile }\end{array}$ & 0.18 & 0.0564 & 0.078 & $0.019-0.14$ & $\begin{array}{l}\text { Box model (using Baetidae or } \\
\text { Perlesta for prey) }\end{array}$ \\
\hline
\end{tabular}

The first turnover column is calculated using the change in the slope of the natural log of the isotope concentration; the second turnover column is calculated from the flux rate estimated with the box models.

nc, not calculated.

the shape and magnitude of the curve (Figure 1A). Collectors, crayfish, and shredders accounted for the largest absolute fluxes of $\mathrm{N}$ among consumer groups (Table 7 ).

\section{Discussion}

\section{Calculation Methods}

We used several methods to estimate $\mathrm{N}$ flux and turnover rates of various food web compartments. Calculating $\mathrm{N}$ turnover using the decline in $\delta^{15} \mathrm{~N}$ values after the tracer addition stopped may have yielded inaccurate results for at least two reasons. First, temperatures were at a maximum at the end of the experiment; consequently, metabolic rates were likely high and not representative of the mean over the entire experiment. This problem would lead to overestimation of rates. Second, many consumers rely upon food sources that continued to contain tracer ${ }^{15} \mathrm{~N}$ after the drip was terminated; this problem causes underestimation of the actual rate. We used Eq. (2) (decline of $\delta^{15} \mathrm{~N}$ ) to estimate turnover for our representative collector (Baetidae spp.) and shredder (Zealeuctra claasseni). Since both were labeled more than their potential food resource, we could not model their uptake based on the label in their food. The relatively high label of Zealeuctra may have been a result of this taxon feeding on FBON in addition to leaves, especially during its early instars. Dobson and Hildrew (1992) classified early instars of another leuctrid, Leuctra, as a collector-gatherer.

The box model approach has some weaknesses as well. It assumes constant biomass and $\mathrm{N}$ uptake per unit biomass through the experiment. Although $\mathrm{N}$ uptake likely increased during the experiment as temperature increased, biomass of the epilithon and filamentous greens was high at the start of the 

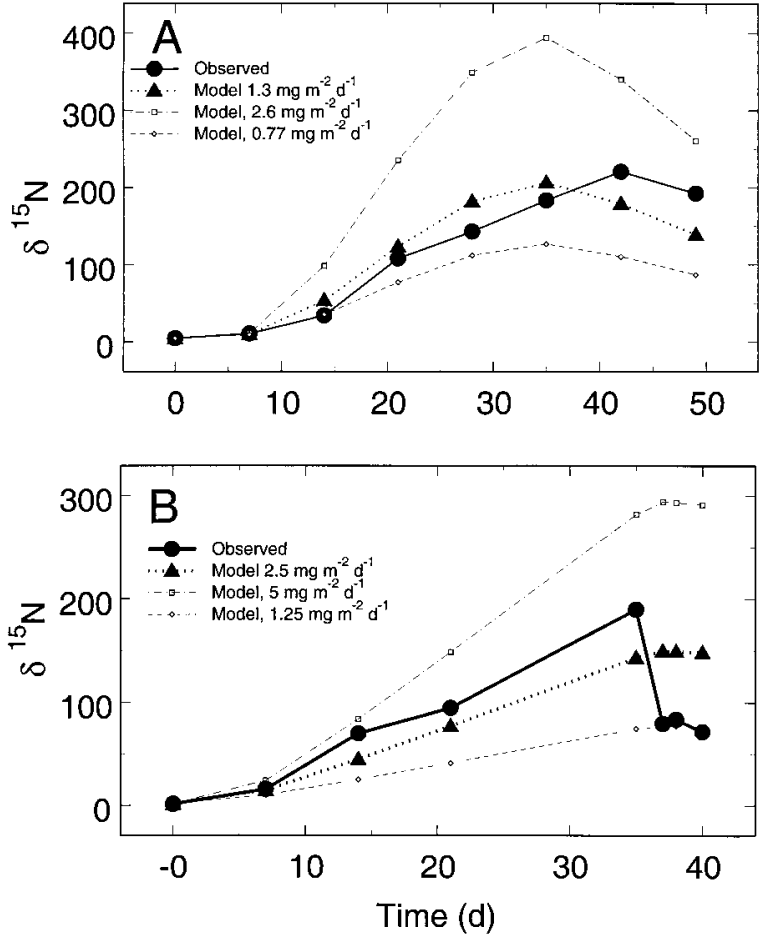

Figure 1. Sensitivity analyses of observed vs modeled ${ }^{15} \mathrm{~N}$ label as a function of modeled $\mathrm{N}$ uptake rate for the invertebrate predator Perlesta placida (A) and epilithon (B) at $50 \mathrm{~m}$ from the ${ }^{15} \mathrm{~N}$ source. The ${ }^{15} \mathrm{~N}$ input was discontinued at day 35 .

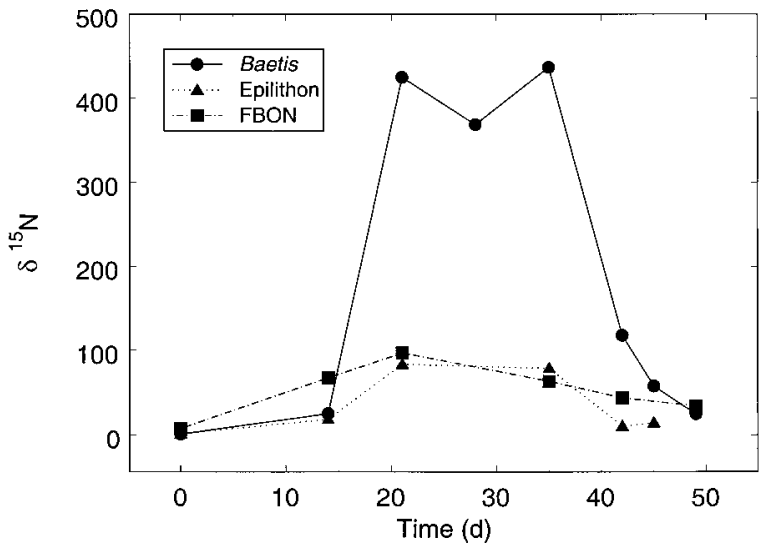

Figure 2. ${ }^{15} \mathrm{~N}$ label of baetid mayflies and their potential food resources, the epilithon and FBON, at the 50-m station throughout the addition of ${ }^{15} \mathrm{~N}$ tracer.

experiment, decreased, and then increased to levels somewhat less than at the start of the experiment by day 35 (data not shown). Fish and crayfish were not present at the beginning of the experiment but migrated into the study reach by day 14. Finally, the box model does not account for the proportion of $\mathrm{N}$ demand satisfied by $\mathrm{NO}_{3}{ }^{-}$uptake for those species that utilize inorganic $\mathrm{N}$, thus leading to underestimates of total $\mathrm{N}$ flux.

Some differences in estimates of $\mathrm{N}$ turnover rates (Table 7) can be attributed to the differences between the two calculation methods. The $\mathrm{N}$ turnover rates estimated for filamentous green algae and epilithon using the turnover method were considerably higher than estimates made with the box model. The fact that the turnover method includes $\mathrm{NO}_{3}{ }^{-}$uptake, whereas the box model does not, could account for the observed discrepancy. In contrast, when trophic relationships were clear (for example, an invertebrate predator and the primary consumers it eats), the model fit the observed data well, and the two methods for estimating turnover rate gave similar results.

\section{Nitrate Flux Estimates}

Incubations using nitrapyrin to estimate $\mathrm{NO}_{3}{ }^{-}$regeneration led to high estimates of nitrification relative to the other techniques. These estimates are high because nitrification that occurs in sediment cores and algal mats that is measured by the nitrapyrin technique may not significantly influence water column $\mathrm{NO}_{3}{ }^{-}$(for example, the nitrate may be assimilated in the benthos before it ever reaches the water column). The modeling approach to estimating water column nitrification using instream ${ }^{15} \mathrm{~N}$ data would not account for this effect. For example, $\mathrm{NO}_{3}{ }^{-}$may undergo denitrification or be assimilated and remineralized as ammonium in the biofilm. Also, laboratory incubations may not be directly comparable to field rates because of bottle effects.

Nitrification rates in the water column calculated using the model should be viewed with caution because the $\mathrm{NO}_{3}{ }^{-}$pool was labeled weakly, leading to lower confidence in model predictions relative to the method used to calculate $\mathrm{NH}_{4}{ }^{+}$turnover. A higher addition rate of $\mathrm{NH}_{4}{ }^{+}$could have alleviated this problem, or ${ }^{15} \mathrm{NO}_{3}{ }^{-}$could have been added and nitrification rates calculated based on uptake and dilution of $\mathrm{NO}_{3}{ }^{-}$. The final method of calculating nitrification, assuming that uptake of $\mathrm{NO}_{3}{ }^{-}$was approximately equal to nitrification, may have provided the best estimates of nitrification. This method must account for addition or dilution of nitrate in regions of significant groundwater input. Given that box model results and uptake methods both are related closely to processes occurring in the water column and shallow benthos, and that results are closer to each other than to the result from the nitrapyrin method, we choose to use the nitrification model and uptake numbers as the range of estimates for nitrification rate. Similar 
Table 8. Ammonium and Nitrate Turnover Rates Reported for Various Aquatic Environments

\begin{tabular}{|c|c|c|c|}
\hline Habitat & $\begin{array}{l}\text { Ammonium } \\
\left(\mathrm{h}^{-1}\right)\end{array}$ & $\begin{array}{l}\text { Nitrate } \\
\left(\mathrm{h}^{-1}\right)\end{array}$ & Reference (year) \\
\hline Prairie stream & $0.5-2.8$ & $0.02-0.31$ & Present study \\
\hline Forest stream (North Carolina) & $2.7-9.8$ & & $\begin{array}{l}\text { Hall and others (1998); Tank and } \\
\text { others (2000) }\end{array}$ \\
\hline Forest stream (Tennessee) & $5.8-8.7$ & $0.41-2.4$ & Mulholland and others (2000) \\
\hline Oligotrophic lake, plankton & $0.002-0.215$ & $0.0004-0.001$ & Dodds and others (1991) \\
\hline Mesotrophic lake, plankton & $0.02-2.1$ & & Haga and others (1995) \\
\hline Eutrophic lake, plankton & $0.16-0.21$ & $0.0004-0.64$ & Gu and others (1997) \\
\hline Eutrophic lake, plankton & 1.3 & & Suttle and others (1990) \\
\hline Long Island Sound, plankton & $0.01-4.6$ & & Suttle and others (1990) \\
\hline Chesapeake Bay, plankton & $0.14-0.30$ & & Glibert and others (1982) \\
\hline Sargasso Sea, plankton & $0.008-0.25$ & & Glibert and others (1982) \\
\hline
\end{tabular}

All rates were calculated assuming constant ambient nutrient concentrations over the measurement period.

All rates were taken from studies using $N$ tracer methods to estimate uptake or remineralization.

rates of nitrification relative to whole-system $\mathrm{N}$ fluxes have previously been documented for an oligotrophic pond (Dodds and Jones 1987; Dodds and Castenholz 1988) and a forested stream (Tank and others 2000).

\section{Whole-stream N Flux Dynamics}

$\mathrm{NH}_{4}{ }^{+}$and $\mathrm{NO}_{3}{ }^{-}$turned over in hours or less in our study, with $\mathrm{NH}_{4}{ }^{+}$turnover rates greater than $\mathrm{NO}_{3}{ }^{-}$ rates. These turnover rates are consistent with those published for other stream studies, but they are much faster than those reported for pelagic systems (Table 8). We hypothesize that turnover rates are higher because the biota in streams have more contact with the volume of water than plankton. The fact that uptake lengths increase with greater discharge (Table 6) supports the idea that the degree of contact with the biota in the benthos heavily influences inorganic $\mathrm{N}$ turnover rates.

The best estimator of $\mathrm{N}$ turnover rates in stream food web compartments was the C:N ratio (Figure 3), which appears to be a reasonable proxy for biological activity. This is not necessarily an expected result. Turnover is calculated per unit $\mathrm{N}$ and could be independent of C:N ratio if the bulk of the nonliving matter in high C:N compartments is C, but the bulk of the $\mathrm{N}$ is contained in biota. Turnover in the high C:N small wood and leaf compartments is attributable to the associated microbial populations. The negative relationship between turnover rate and C:N ratio may indicate a pool of $\mathrm{N}$ in the high C:N ratio compartments that is recalcitrant and not involved in $\mathrm{N}$ cycling. Alternatively, the organisms living in a high $\mathrm{C}: \mathrm{N}$ matrix may retain their nitrogen more efficiently or be less metabolically

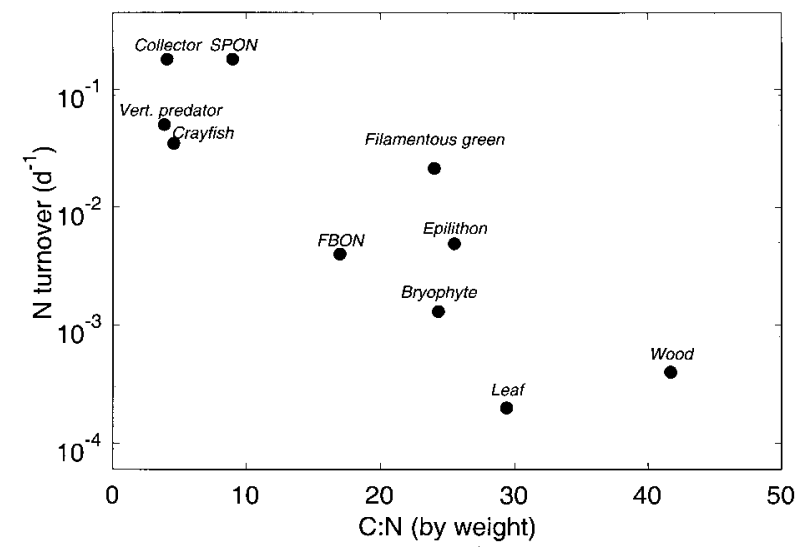

Figure 3. Relationship between $\mathrm{N}$ turnover and C:N ratio. $\mathrm{N}$ turnover rates from Table 6 were taken from the model calculations. Regression analysis yielded the relationship $\log _{10}$ (turnover) $=-0.77+0.0702 \times \mathrm{C}: \mathrm{N}$ with an adjusted $r^{2}$ of 0.7 .

active. This result is interesting, because it may allow for ecosystem models to be constructed in the absence of turnover measurements if mass estimates and $\mathrm{C}: \mathrm{N}$ ratios are available. It is not certain that this relationship is generally true; our C: $\mathrm{N}$ values were similar but our turnover rates were generally one-tenth of those reported for two forested streams (Mulholland and others 2000; Tank and others 2000).

We attempted to relate $\mathrm{N}$ turnover to invertebrate growth (Figure 4), but no relationship was found. We could argue (a priori) that more metabolically active animals (those with high $\mathrm{N}$ turnover rates) should grow more rapidly than those with lower turnover rates. However, the data do not support this view. Labeling experiments seem to be 


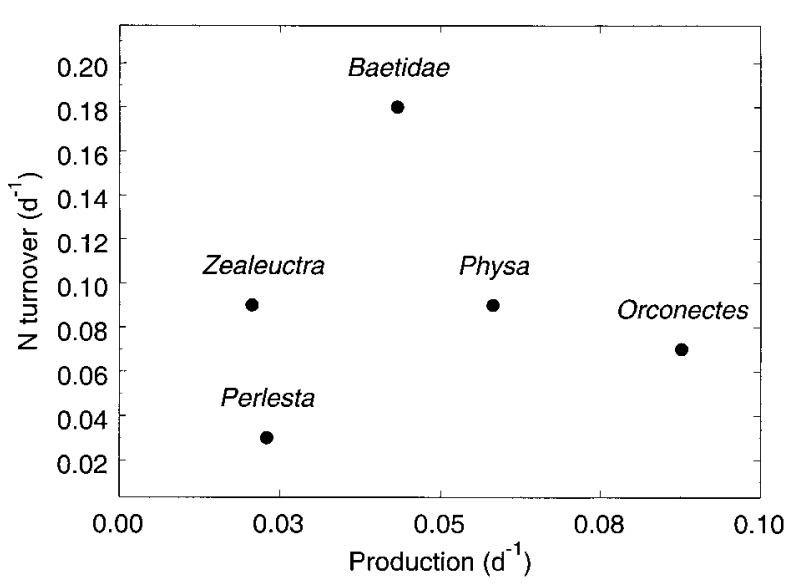

Figure 4. Lack of relationship between production (growth) and $\mathrm{N}$ turnover rates for selected invertebrate taxa.

necessary to estimate $\mathrm{N}$ uptake and turnover rates in individual invertebrate taxa.

Means of all the measured or directly estimated food web $\mathrm{N}$ fluxes are summarized in Figure 5. Our approach differs from many other published flux diagrams for ecosystems because we have not forced the system to be balanced. Imbalances emphasize weak points in our ability to quantify $\mathrm{N}$ cycling in this food web. Our budget did not balance in some cases (that is, all fluxes into a compartment did not equal fluxes out of a compartment) because of experimental limitations or potential errors in measurements. In other cases, assumptions of steady state, diet, or assimilation were incorrect, and the budget would not be expected to balance over the spatial and temporal scales of our experiment. Estimates and potential errors of $\mathrm{N}$ fluxes through water column nutrients, primary $\mathrm{N}$ uptake compartments, primary consumers, and finally predators will be discussed below.

Dissolved $\mathrm{N}$ compartments were transported downstream in the water column more quickly than they were taken up (that is, the flux associated with water flow across each $\mathrm{m}^{2}$ is greater than the uptake or regeneration rates for all forms of dissolved N). Ammonium export was about 50 times greater than total uptake and remineralization. In contrast, DON production rates were almost 300,000 times less than transport (Figure 5).

Primary pathways of $\mathrm{NH}_{4}^{+}$into the food web were through the FBON and epilithon pools, and the calculated total was $2.6 \mathrm{mg} \mathrm{m}^{-2} \mathrm{~d}^{-1}$. Total influx into epilithon and FBON exceeded uptake by consumers, indicating significant remineralization directly from these compartments. However, denitrification in the FBON may be significant, and we cannot account for this flux. Other research on this stream suggests low rates of denitrification (Kemp unpublished).

Total uptake of $\mathrm{NH}_{4}{ }^{+}$exceeded estimated production of $\mathrm{NO}_{3}{ }^{-}$, so $\mathrm{NH}_{4}{ }^{+}$was likely to be the most important source of dissolved inorganic $\mathrm{N}$ to the primary uptake compartments (epilithon, FBON, wood) in this stream. We could not detect changes in nitrate as we sampled downstream through the study reach. Thus, in the absence of major growth [Eq. (6)], uptake is expected to approximately equal remineralization. Since remineralization (nitrification) of $\mathrm{NO}_{3}{ }^{-}$was about one-tenth that of $\mathrm{NH}_{4}{ }^{+}$ uptake, we hypothesize that $\mathrm{NH}_{4}{ }^{+}$uptake was more important than $\mathrm{NO}_{3}{ }^{-}$uptake during this study.

Wood, bryophytes, crayfish, Campostoma, vertebrate predators, and other invertebrate groups that did not emerge accumulated $\mathrm{N}$ over the duration of our study. If we extrapolated this trend, these compartments eventually would fill the stream. Scouring floods and microbial degradation of bryophytes and wood could cause $\mathrm{N}$ release, but these factors were not measured in this study. A strong influence of scouring floods on epilithon has been demonstrated for this stream (Dodds and others 1996b), and floods influence export of all the compartments. Most of the consumers eventually die when the stream channel dries, or predators such as raccoons, water snakes, and herons remove them.

Adult insects emerge from the channel to reproduce, leading to a net loss of N. Data from Gray (1993) were used to estimate this $\mathrm{N}$ loss from our study reach. The ratio of adult emergence production to benthic biomass from Gray's prior study was applied to the benthic biomass and percentage $\mathrm{N}$ measurements from this study. Estimated rates of emergence were $0.7,1.25,0.02$, and $0.1 \mathrm{mg} \mathrm{N} \mathrm{m}^{-2}$ $\mathrm{d}^{-1}$ for collectors, invertebrate predators, scrapers, and shredders, respectively. These rates are similar to our uptake estimates (Figure 5), but emergence of many taxa in our site centers on spring (Gray 1993), the time of year that our study took place. During most months of the year, uptake continues with no emergence, allowing for a few months where estimates of $\mathrm{N}$ loss from emergence can equal or exceed estimates of $\mathrm{N}$ uptake.

Crayfish are important consumers of detritus (Huryn and Wallace 1987) and algae (Hart 1992; Creed 1994) as well as significant predators (see, for example, Lodge and others 1994; Lamberti 1996), both our data and the results of Whitledge and Rabeni (1997) validate this on an ecosystem level. Campostoma may be an important consumer of algal biomass in some streams (Matthews and others 


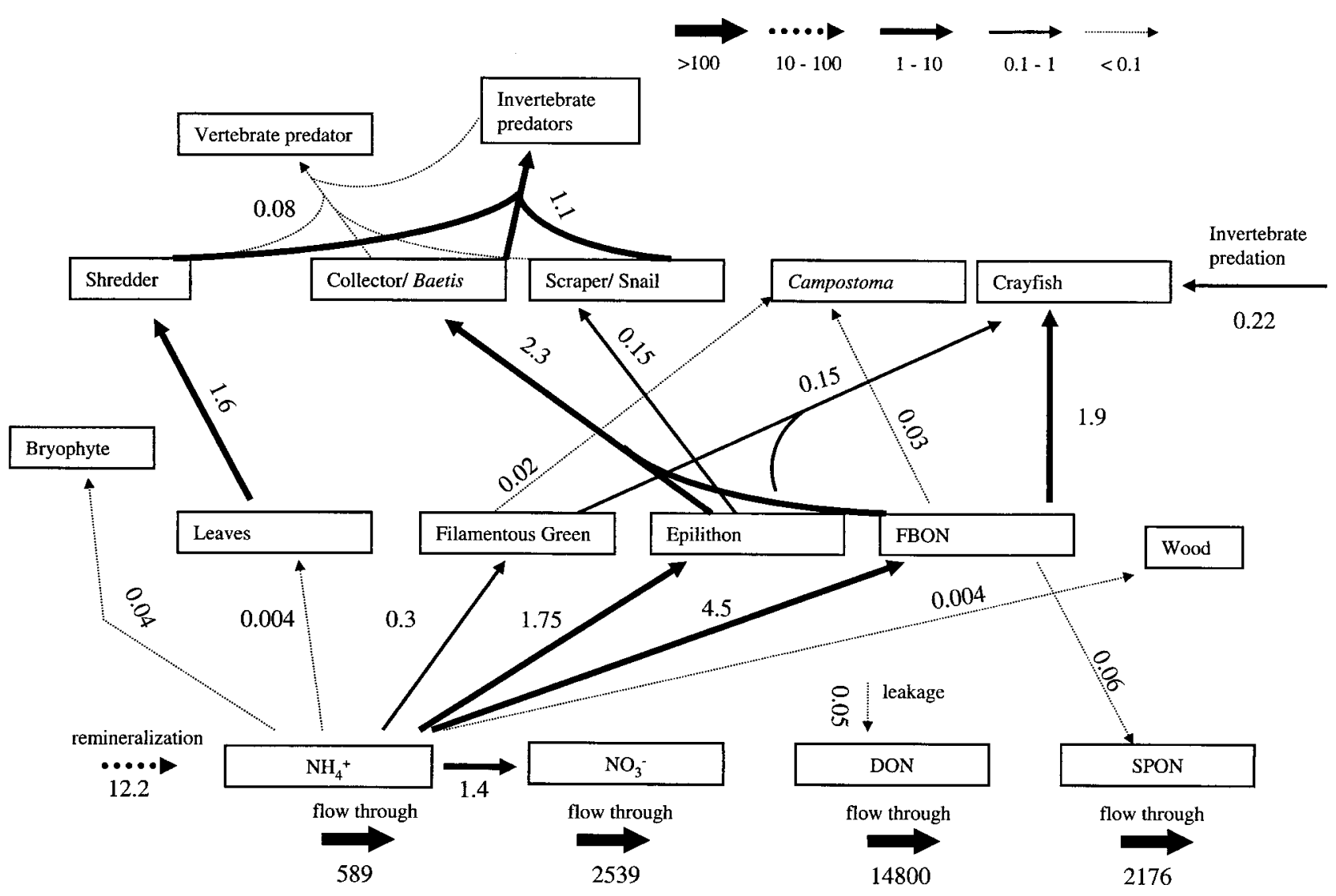

Figure 5. Diagram of fluxes directly measured or estimated in this study. All fluxes are given in $\mathrm{mg} \mathrm{N} \mathrm{m}^{-2} \mathrm{~d}^{-1}$. The size of the arrow corresponds to the magnitude of the flux, and the size of the box is independent of biomass. Flow through is the amount moving across each $\mathrm{m}^{2}$ in the water column per unit of time.

1987; Power and others 1988; Gelwick and Matthews 1992), although gut analyses have shown that stonerollers as consumers can ingest a considerable amount of detritus (Kraatz 1923; Burkhead 1980; Fowler and Taber 1985).

Few studies have directly characterized the relative importance of crayfish and stonerollers on an ecosystem level. Our data suggest crayfish are more important than Campostoma as a consumer of $\mathrm{N}$ from the algal components in Kings Creek. The relative importance of these two organisms as grazers may be related to the low biomass of Campostoma compared to crayfish. Crayfish are more adapted to persisting in this intermittent stream because they are capable of burrowing to avoid dessication. Campostoma must move into the experimental reach from permanent downstream and upstream reaches when conditions are favorable and may take longer to populate intermittent reaches.

Shredders take up much more $\mathrm{N}$ than enters the leaf compartment (Figure 5). This imbalance would be explained if a significant portion of the $\mathrm{N}$ used by shredders actually is contained in the leaves that enter the stream. Also, as discussed previously, our focal shredder, Zealeuctra, may be a collector during early instars.

The $\mathrm{N}$ cycle in this prairie stream was moderately efficient with regard to $\mathrm{N}$ transfer. Total uptake of $\mathrm{NH}_{4}{ }^{+}$and $\mathrm{NO}_{3}{ }^{-}$was $9.3 \mathrm{mg} \mathrm{m}^{-2} \mathrm{~d}^{-1}$. Total consumption of the filamentous green algae, epilithon, FBON, and leaves was $6.2 \mathrm{mg} \mathrm{m}^{-2} \mathrm{~d}^{-1}$. Predation on these primary consumers was $1.4 \mathrm{mg} \mathrm{m}^{-2} \mathrm{~d}^{-1}$. Therefore, ecosystem flux rates through invertebrate predators were not higher than those through other invertebrates even though their biomass values were similar. Production (expressed per unit N) of the $1^{\circ}$ consumers could more than supply production of the aquatic predators in this stream. Invertebrate predators account for a relatively large portion of total invertebrate biomass in Kings Creek (see Table 3) (Gray and Johnson 1988; Gray and Dodds 1998). Despite the high predator biomass, results of our investigation of $\mathrm{N}$ cycling indicate that turnover rates of primary consumer groups are sufficient to account for the approximately equal biomass of predators and consumers. Accounts of en- 
ergy flow in other streams also have demonstrated that apparent trophic imbalances (for example, the Allen Paradox), (Hynes 1970) can be explained by high turnover rates of primary consumers (Waters 1979; Benke 1984).

About $23 \%$ of added ${ }^{15} \mathrm{~N}$ remained in biomass at the end of our experiment, indicating a significant amount of retention along the $210-\mathrm{m}$ stream reach. Less than $1 \%$ of the label flowed out in the form of dissolved nutrients; most of it left in the particulate form. In a similar experiment on a deciduous forest stream in Tennessee, $33-48 \%$ of the ${ }^{15} \mathrm{~N}$ was retained in biomass, and $25 \%$ was exported as inorganic nutrients (Mulholland and others 2000). In a North Carolina deciduous forest steam, biomass retained $12 \%$ of the ${ }^{15} \mathrm{~N}$ and $30 \%$ was exported as dissolved nutrients (Tank and others 2000). The retention by biota in our system was similar to the two other studies, but both studies documented greater relative export of label in the form of dissolved inorganic $\mathrm{N}$ than we did.

The flowthrough $\mathrm{N}$ fluxes were high when expressed on a per $\mathrm{m}^{2}$ basis (Figure 5), but there are several hundred $\mathrm{m}^{2}$ for interaction with the $\mathrm{N}$ added to the water column before it flows out of the study reach. We were unable to partition the remaining retention of added ${ }^{15} \mathrm{~N}$, because we were missing two potential fluxes of $\mathrm{N}$. In addition to denitrification, ${ }^{15} \mathrm{~N}$ was also taken up by roots of riparian vegetation up to several meters away from the stream channel (D. Sanzone, personal communication).

In conclusion, the primary uptake compartments took much of their $\mathrm{N}$ from $\mathrm{NH}_{4}{ }^{+}$. Transport of DON was a primary flux of $\mathrm{N}$ through the system, though it was not actively cycled through the biota. The rate of $\mathrm{N}$ turnover was correlated strongly with $\mathrm{C}: \mathrm{N}$ ratio. Each trophic level was moderately efficient at $\mathrm{N}$ transfer, as might be expected with cycling of $\mathrm{N}$ compared to carbon, which is respired as well as used for growth. The 210-m reach retained onefourth of the added ${ }^{15} \mathrm{NH}_{4}{ }^{+}$during the approximately 1-month study.

\section{ACKNOWLEDGMENTS}

We thank Rosemary Ramundo, Amanda Kuhl, Diane Sanzone, Alex Corum, Jay Jeffrey, Chris Guy, and Bert Lewis for field and lab assistance. Jack Webster and Pat Mulholland provided assistance with calculations and conceptual guidance. Kris Tholke, Max Holmes, and Rosemary Ramundo provided expert analytical assistance. Judy Meyer and Diane Sanzone did C and N content analyses. Pat Mulholland measured stream $\mathrm{P}$ and $\mathrm{R}$ rates. Breck Bowden and an anonymous reviewer provided helpful comments on the manuscript. This research was funded by the National Science Foundation, which supported the Lotic Intersite Nitrogen Experiment and the Konza Prairie Long-Term Ecological Research grants. This is contribution number 00-2-J from the Kansas Agricultural Experiment Station.

\section{REFERENCES}

Ameel JJ, Axler RP, Owen CJ. 1993. Persulfate digestion for determination of total nitrogen and phosphorus in low-nutrient waters. Am Environ Lab 10:7-10.

American Public Health Association. 1995. Standard methods for the examination of water and wastewater. 19th ed. Washington, (DC): American Public Health Association.

Benke AC. 1984. Secondary production of aquatic insects. In: Resh VH, Rosenberg DM, editors. The ecology of aquatic insects. New York: Praeger. p 289-322.

Benke AC, Huryn AD, Smock LA, Wallace JB. 1999. Lengthmass relationships for freshwater macroinvertebrates in North America with particular reference to the southeastern United States. J North Am Benthol Soc 18:308-43.

Benke AC, Wallace JB. 1980. Trophic basis of production among net-spinning caddisflies in a southern Appalachian stream. Ecology 61:108-18.

Burkhead NM. 1980. The life history of the stoneroller minnow, Campostoma A. anomalum (Rafinesque), in five streams in east Tennessee [thesis]. Knoxville (TN): University of Tennessee.

Creed RP. 1994. Direct and indirect effects of crayfish grazing in a stream community. Ecology 75:2091-103.

Cross FB, Collins JT. 1995. Fishes in Kansas. Lawrence: Kansas Museum of Natural History publication. Education Series No. 14. $315 \mathrm{pp}$.

Crossley DA Jr, Reichle DE. 1969. Analysis of transient behavior of radioisotopes in insect food chains. BioScience 19:341-3.

Dobson M, Hildrew AG. 1992. A test of resource limitation among shredding detritivores in low order streams in England. J Anim Ecol 61:69-77.

Dodds WK. 1993. What controls levels of dissolved phosphate and ammonium in surface waters? Aquat Sci 55:132-42.

Dodds WK. 1997. Distribution of runoff and rivers related to vegetative characteristics, latitude, and slope: a global perspective. J North Am Benthol Soc 16:162-8.

Dodds WK, Blair JM, Henebry GM, Koelliker JK, Ramundo R, Tate CM. 1996a. Nitrogen transport from tallgrass prairie by streams. J Environ Qual 25:973-81.

Dodds WK, Castenholz RW. 1988. The nitrogen budget of an oligotrophic cold water pond. Arch Hydrobiol Suppl 4:343-62.

Dodds WK, Jones RD. 1987. Potential rates of nitrification and denitrification in an oligotrophic freshwater sediment system. Microbial Ecol 14:91-100.

Dodds WK, Priscu JC. 1990. Mesocosm studies on the influence of phosphate enrichment on ammonium and nitrate flux in an oligotrophic lake. Hydrobiologia 206:235-43.

Dodds WK, Priscu JC, Ellis BK. 1991. Seasonal uptake and regeneration of inorganic nitrogen and phosphorus in a large oligotrophic lake: size fractionation and antibiotic treatment. J Plankt Res 13:1339-58.

Dodds WK, Hutson RE, Eichem AC, Evans ME, Gudder DA, Fritz KM, Gray L. 1996b. The relationship of floods, drying, flow 
and light to primary production and periphyton biomass in a prairie stream. Hydrobiologia 133:151-9.

Dodds WK, Smith VH, Zander B. 1997. Developing nutrient targets to control benthic chlorophyll levels in streams: a case study of the Clark Fork River. Water Res 31:1738-50.

Fowler JF, Taber CA. 1985. Food habits and feeding periodicity in two sympatric stonerollers (Cyprinidae). Am Midl Nat 113: 217-23.

Gelwick FP, Matthews WJ. 1992. Effects of an algivorous minnow on temperate stream ecosystem properties. Ecology 73: $1630-45$.

Glibert PM, Lipschultz F, McCarthy JJ, Altabet MA. 1982. Isotope dilution methods of uptake and remineralization of ammonium by marine phytoplankton. Limnol Oceanogr 27:63950.

Gray LJ. 1993. Response of insectivorous birds to emerging aquatic insects in riparian habitats of a tallgrass prairie stream. Am Midl Nat 129:288-300.

Gray LJ, Dodds WK. 1998. Structure and dynamics of aquatic communities. In: Knapp AK, Briggs JM, Hartnett DC, Collins SL, editors. Grassland dynamics: long-term ecological research in tallgrass prairie. New York: Oxford University Press. p 17789.

Gray LJ, Johnson KW. 1988. Trophic structure of benthic macroinvertebrates in Kings Creek. Trans Kansas Acad Sci 91: $178-84$.

Gray L, Macpherson GL, Koelliker JK, Dodds WK. 1998. Hydrology and aquatic chemistry. In: Knapp AK, Briggs JM, Hartnett DC, Collins SL, editors. Grassland dynamics: long-term ecological research in tallgrass prairie. New York: Oxford University Press. p 160-89.

Gu B, Havens KE, Schelske CL, Rosen BH. 1997. Uptake of dissolved nitrogen by phytoplankton in a eutrophic subtropical lake. J Plankt Res 19:759-70.

Haga H, Nagata T, Sakamoto M. 1995. Size-fractionated $\mathrm{NH}_{4}{ }^{+}$ regeneration in the pelagic environments of two mesotrophic lakes. Limnol Oceanogr 40:1091-9.

Hall GH. 1984. Measurement of nitrification rates in lake sediments: comparison of the nitrification inhibitors nitrapyrin and allylthiourea. Microbial Ecol 10:25-36.

Hall RW Jr, Peterson BJ, Meyer J. 1998. Testing a nitrogencycling model of a forest stream by using a nitrogen- 15 tracer addition. Ecosystems 1:283-98.

Hart DD. 1992. Community organization in streams: the importance of species interactions, physical factors and chance. Oecologia 91:220-8.

Holmes RO Jr, McClelland JW, Sigman DM, Fry B, Peterson BJ. 1998. Measuring ${ }^{15} \mathrm{~N}_{-} \mathrm{NH}_{4}{ }^{+}$in marine, estuarine, and fresh waters: an adaptation of the ammonium diffusion method for samples with low ammonium concentrations. Mar Chem 60: 235-43.

Huryn, AD, Wallace JB. 1987. Production and litter processing of crayfish in an Appalachian mountain stream. Freshwater Biol. 18:277-86.

Hynes HBN. 1970. The ecology of running waters. Toronto: University of Toronto Press. $555 \mathrm{pp}$.

Kraatz WC. 1923. Study of the food of the minnow, Campostoma anomalum. Ohio J Sci 23:265-83.

Lamberti GA. 1996. Role of periphyton in benthic food webs. In: Stevenson RJ, Bothwell ML, Lowe RL, editors. Algal ecology: freshwater benthic ecosystems. San Diego: Academic Press. p 533-72.
Laws E. 1984. Isotope dilution models and the mystery of vanishing ${ }^{15} \mathrm{~N}$. Limnol Oceanogr 29:379-86.

Lawton JH. 1970. Feeding and food energy assimilation in larvae of the damselfly Pyrrhosoma nymphula (Sulz.) (Odonata: Zygoptera). J Anim Ecol 40:385-423.

Lodge DM, Kershner MW, Alot JE. 1994. Effects of an omnivorous crayfish (Orconectes rusticus) on a freshwater littoral food web. Ecology 75:1265-81.

Matthews WS. 1988. North American prairie streams as systems for ecological study. J North Am Benthol Soc 7:387-409.

Matthews WJ, Stewart AJ, Power ME. 1987. Grazing fishes as components of North American stream ecosystems: effects of Campostoma anomalum. In: Matthews WJ, Heins DC, editors. Community and evolutionary ecology of North American stream fishes. Norman (OK): University of Oklahoma Press. p $128-35$.

Momot WT. 1984. Crayfish production: a reflection of community energetics. J Crust Biol 4:35-54.

Mulholland PJ, Tank JL, Sanzone DM, Wollheim WM, Peterson BJ, Webster JR, Meyer JL. 2000. Nitrogen cycling in a forest stream determined by a ${ }^{15} \mathrm{~N}$ tracer addition. Ecol Monogr 70:471-493.

Odum HT. 1957. Structure and productivity of Silver Springs, Florida. Ecol Monogr 27:55-112.

Oviatt CG. 1998. Geomorphology of Konza Prairie. In: Knapp AK, Briggs JM, Hartnett DC, Collins SL, editors. Grassland dynamics: long-term ecological research in tallgrass prairie. New York: Oxford University Press. p 35-47.

Perry WB, Benfield EF, Perry SA, Webster JR. 1987. Energetics, growth, and production of a leaf-shredding aquatic insect in an Appalachian Mountain stream. J North Am Benthol Soc 6:12-25.

Peterson BJ, Bahr M, Kling GW. 1997. A tracer investigation of nitrogen cycling in a pristine tundra river. Can J Fish Aquat Sci 54:2361-67.

Power ME, Stewart AJ, Matthews WJ. 1988. Grazer control of algae in an Ozark Mountain stream: effects of short-term exclusion. Ecology 69:1894-8.

Sigman DM, Altabet MA, Michener R, McCorkle DC, Fry B, Holmes RM. 1997. Natural abundance-level measurement of the nitrogen isotopic composition of oceanic nitrate: an adaptation of the ammonia diffusion method. Mar Chem 57:227-42.

Stream Solute Workshop. 1990. Concepts and methods for assessing solute dynamics in stream ecosystems. J North Am Benthol Soc 9:95-119.

Suttle CA, Fuhrman JA, Capone GD. 1990. Rapid ammonium cycling and concentration-dependent partitioning of ammonium and phosphate: implications for carbon transfer in planktonic communities. Limnol Oceanogr 35:424-33.

Tank JL, Meyer JL, Sanzone DM, Mulholland PJ, Webster JR, Peterson BJ, Wollheim WM, Leonard NE. 2000. Analysis of nitrogen cycling in a forest stream during autumn using a ${ }^{15} \mathrm{~N}$-tracer addition. Limnol Oceanogr 45:1013-1029.

Tate CM. 1990. Patterns and controls of nitrogen in tallgrass prairie streams. Ecology 71:2007-18.

Technicon Autoanalyzer II. 1973. Nitrate and nitrite in water and wastewater. Industrial Method Number 100-70w. Tarrytown (NY): Technicon Industrial Systems.

Triska F, Sedell J, Cromack K Jr, Gregory S, McCorison FM. 1984. The nitrogen budget for a small coniferous forest stream. Ecol Monogr 54:119-40. 
Van Den Avyle MJ. 1993. Dynamics of exploited fish populations. In: Kohler CC, Hubert WA, editors. Inland fisheries management in North America. Bethesda (MD): American Fisheries Society. p 105-35.

Waters TF. 1979. Influence of benthos life history upon the estimation of secondary production. J Fish Res Bd Can 36: 1425-30.

Webster R, Ehrman TP. 1996. Solute dynamics. In: Hauer FR, Lamberti GA, editors. Methods in stream ecology. San Diego: Academic Press. p 145-60.

Whitledge GW. 1996. Trophic ecology of crayfish in the Jacks
Fork River, Missouri [thesis] Columbia (MO): University of Missouri.

Whitledge GW, Rabeni CF. 1997. Energy sources and ecological role of crayfishes in an Ozark stream: insights from stable isotope and gut analysis. Can J Fish Aquat Sci 54: 2555-63.

Wollheim WM, Peterson BJ, Deegan LA, Bahr M, Hobbie JE, Jones D, Bowden WB, Hershey AE, Kling GW, Miller MC. 1999. A coupled field and modeling approach for the analysis of nitrogen cycling in streams. J North Am Benthol Soc 18: 199-221. 